Research Article

Mario De Benedetti*

\title{
Bruno Leoni's Concept of Law and Representation in The Cyber Age: A Cybernetic Model
}

https://doi.org/10.1515/openps-2020-0005

received February 28, 2020; accepted March 17, 2020.

\begin{abstract}
The purpose of this article is to contextualize Bruno Leoni's political theory within the Digital Information Society, a new dimension of public participation in the political arena and a sign of the democratic transition through new forms of involvement by public opinion. In particular, the evolution of the Information Society will be briefly examined starting from the studies of Fritz Machlup, considered its progenitor, to pass to the examination of the Leonian concept of law and politics in the technological society, with reference to Norbert Wiener and Karl Deutsch's cybernetic theory. This paper will attempt to describe the evolutive process of political participation in democratic society by reinterpreting the thought of Bruno Leoni concerning Democracy, the State and the homo telematicus in the digital social order.
\end{abstract}

Keywords: Bruno Leoni; Representation; Internet; Feedback.

\section{The Information Society: from Cybernetics to Cyberspace}

The particular sensibility shown by Bruno Leoni to interpret law and politics has proved to be able to extend well beyond the times when the well-known jurist elaborated his thought. In particular, in reading the first pages of his text Freedom and the $L a w^{1}$, it is possible to see a forerunner of what will become the academic debate on law and democracy in the digital age, in addition to guessing the importance of communication and knowledge in the technological society in parallel with the emerging studies on cybernetics.

In 1943 Norbet Wiener, Arturo Rosenbleuth and Julian Bigelow wrote an article ${ }^{2}$ that set the foundations of the cibernetic theory, concerning the definition of communication and purpose as a matter of informations flows conducted into a system (biological, electronic or political) through a behaviour, defined as a "change of an entity with respect to its surroundings", or an action that involves perceptible changes from the outside in a given context.

The term they used to summarize the finalistic and teleological aspect of this action was "feedback", referring to a communication system that produces an action in response to an aprioristic information input, which includes the results of its action translated in a new information through which change any subsequent behavior ${ }^{3}$.

To have a feedback, we need specific informations to use as inputs, in order to get the answers we need, translated into behaviours; these informations come from an aprioristic knowledge (or a signal in electrical systems) that human beings possess, knowledge acquired in time with practical or theorical experience, enhanced by the use of electrical o electroni machines or media.

In the post-industrial society knowledge is the new currency of exchange in the labour market of a new system, the Information Society.

In 1962, the austrian born economist Fritz Machlup published a study ${ }^{4}$ concerning the relevance of knowledge in the United States economy; this study, starting from the evaluation of the patent system, brought to light that the average level of American education between 1900 and 1959 rose exponentially and that, thanks also to the use of

*Corresponding author: Mario De Benedetti, Guglielmo Marconi University, Rome, Italy, E-mail: mdebenedetti81@gmail.com 
new tools such as cinema, telephone and new electronic computers, knowledge became so relevant in the American economy ${ }^{5}$ to impose a new frontier in the industrial landscape based not on physical labor, but on intellectual labor (or 'knowledge producing' labour, with a specific reference to 'knowledge workers')6.

Although Machlup admitted that Adam Smith ${ }^{7}$ himself referred to knowledge in the labour market, the Austrian economist pointed out that, since then, most economists treated knowledge as an exogenous variable, while he proposed considering it as an endogenous spoil for the purpose of measuring economic growth.

Knowledge became a valuable skill capable to create a new economy: this was the intuition of Daniel Bell, who in 1973 formalized the terms of Information Society and Post-industrial Society, as well as formulating a theory that anticipated the transformation of social relations with the advent of the World Wide Web ${ }^{8}$.

The two dimensions of the Post-industrial society are "the centrality of the theoretical knowledge and the expansion of services in the economic sector" ${ }^{\prime}$ and three very specific aspects are indicated by the author to characterize the contents that allow interaction between individuals: data, as the basic information used to describe the empirical environment; information flows, meaning the organization of such data in coherent and understandable schemes; knowledge, or the means that individuals use to process information and make judgments, through the use of the technology offered by the computer-driven revolution ${ }^{10}$.

Knowledge and technology, an ancient combination that has found its apogee in the development of the media, in particular of cinema and television first ${ }^{11}$ and, more recently, of the massive use of computers, digital technologies and social networks that have redesigned a new configuration of the individual in the digital space, named homo telematicus, an incorporeal anthropological mutation that travels and interacts with other incorporeal entities in virtual communities, located in a space without physical limits, without precise rules and infinite potential of access to a mass of information otherwise difficult to access.

This telematic reality got a name in 1982, thanks to the almost dreamlike invention of the concept of cyberspace by the writer William Gibson ${ }^{12}$, at the dawn of the launch of that public access network that in 1983 will be named 'the Internet ${ }^{13}$; a new dimension, where the authoritative power of states had no value and where individuals with farsighted visions could create new social systems of coexistence and sharing of ideas in any area of human knowledge.

The transition to the Information Society and to cyberspace marks the overcoming of the connection between community of men and territory: a new world in which a new nomos ${ }^{14}$ materializes, devoid of the telluric connection delineated by Carl Schmitt, but which arises from the spontaneous meeting of the will of the individuals who interact on the network, without that institutional intermediation (bureaucracy, courts, political parties) that in physical reality it freezes the active participation of people in a rigid and coercive legislation ${ }^{15}$.

\section{Law, Politics and Technology: the Leonian perspective on democratic representation}

Cyberspace, therefore, represents a new system of channeling human communication, which allows to reinterpret the social dynamics that guarantee the stability of democratic regimes.

Defining the characteristics of democracy is a work that many have accomplished ${ }^{16}$, and for this reason the task of this paper goes beyond a further attempt to define it. However, it seems useful to start from the warning that Giovanni Sartori himself profounds in the work of conceiving the essence of the democratic model, namely that of connecting the 'prescriptive' definition (what democracy should be) with the 'descriptive' definition (what democracy concretely is $)^{17}$. In other words, the parallel between ideals and facts must be elaborated without identifying one or the other in isolation with the concept that one intends to investigate.

Following the path traced by the studies on cybernetics, we can define this meeting of variables as the construction of a theoretical model, which can be more or less adequate to a given empirical situation depending on a sum of criteria that makes up the scientific knowledge process: selective interests, the characteristics of the situation to be known, selection operations, the system of symbols and physical instruments by which the selected data are recorded for subsequent applications ${ }^{18}$. In this way a cognitive process is configured in which the subjective and objective elements meet, generating an information output that can in turn become the object of stratified interpretations to be used according to the situations. Choosing a model that adapts to a given empirical situation means knowing how 
to orientate oneself through the criteria that characterize it, namely its realism (or "relevance", the adherence of the model to the empirical system that one intends to describe) and its "cheapness" (a greater simplicity that allows the elaboration of generalizable statements for a multitude of situations) ${ }^{19}$.

In addition to these elements, a model must have its own predictive ability, with which to indicate new fields of investigation: this forecasting capacity is guaranteed by the rigor of the model, its combinatorial richness, the power to correspond to empirical processes further to those for which it is been generated. Finally it must be taken into account that the usefulness of an empirical theory is also the originality of a model: the more it is characterized by a high degree of originality and generality, the more ductile and resistant it will be to the criticisms deriving from changing historical paradigms and cultural aspects that characterize society. A model that is no longer able to counter the need for alternative models is no longer useful to the scientist and is condemned to oblivion.

The versatility of democratic theory has allowed its survival so far, despite the deep criticisms that have been made of it; however, the disintegration of confidence in the democratic model seems to be substantiated precisely in the contrasted relationship between subjectivity and objectivity of the concept of democracy, or rather on the gap between democratic ideals and real democracy.

The deformation of the resulting information output translates into reality as the perceived interruption of the relationship between the voters and their representatives ${ }^{20}:$ a break in communication that does not produce the expected or imagined result. The introduction into the political system of the aid of ICT technologies represents, in the collective imagination, the definitive tool to restore the connection between citizens and the political class, strengthening the role of the demos in influencing the decisions taken at the institutional level.

The study of the union between democratic principles and technology is of fundamental importance for the meditation on the transformation of traditional democratic values since, in the Information Society, both society and politics are increasingly overbearing digital. Cyberspace and the Internet, in particular, are used both for consensus building and for the manifestation of a dissent that reaches ever more extreme levels, which sometimes takes the form of real acts of digital terrorism.

This systemic complexity, deriving from the widespread influence on the economic, juridical and political relational dynamics of technology, has been intercepted and interpreted by Bruno Leoni in his most mature phase as a sign of an initial disintegration of the traditional pillars that support the scaffolding of democratic societies: legislation and political representation. In his reflections on freedom, Leoni harshly criticizes those who justify the expansion of legislative production as a response to the challenges arising from technological progress, responding that coercive law develops in a way diametrically opposed to the development of science: the first as the result of a process where the will and authority of an imposed majority of legislators prevails, while the second is always derived from the free initiative of small individuals, who often face the resistance of the authoritarian majority ${ }^{21}$.

In particular, Leoni focuses on protecting the freedom of the individual within the technology-dominated society, believing that the legislator who imposes himself as a representative of the citizen in the legislative process ends up identifying himself with the ruling class of a planned economy system whose decisions, based on a limited knowledge of reality, are forced upon the members of the community. This continuous extension of the principle of representation both to the field of law and to the field of politics, is criticized by Leoni precisely because it produces disaffection on the part of individuals with regard to the decision-making process, which they consider too onerous to access the mass of information and data more and more redundant thanks to the progress of technologies; for this reason, active participation is increasingly restricted to those small parts of society that do not perceive the information process as an insurmountable social cost, while the others delegate decisions to their representatives with greater ease and frequency ${ }^{22}$.

In a social reality governed by collective decisions that are the result of procedures ${ }^{23}$ followed by a few members of a particular group, whose consequences translate into rules valid for each single member of the group, including those who do not agree with them, freedom of individual action is greatly compressed ${ }^{24}$ : the social coercion that these decisions entail is embodied according to Leoni, who welcomes Popper's intuition on the degree of closure of a social context that sacrifices individual interest to the collective one $\mathrm{e}^{25}$, in that rule of the majority that characterizes democratic systems, which contrasts the involuntary order that comes from the rational exchange of individual behaviors that Leoni defines as "claims"26.

In his reflection on the inadequacy of the majority representation in the juridical and political field within the societies characterized by a high degree of technological development, Leoni anticipates what Paul Virilio will call 
"dromocratic society" 27 , that is a comunity characterized by the high speed of transmission, processing and data transformation; in this context, according to Leoni, the crisis of modern democracies does not derive from the difficulty of democratic regimes to adapt to a world in continuous evolution, but from the capacity of the majority principle itself to suppress the freedom of unsuccessful minorities.

In the age of digital speed, even the rigid traditional legislative apparatus is no longer able to respond to the needs of a complex system, based on the extreme freedom of circulation of information guaranteed by cyberspace and the Internet which, as much as it is the fruit of human architecture ${ }^{28}$, has allowed the evolution of a spontaneous order based on multistakeholder governance, a regulatory system based on the voluntary and non-conflictual competitive interaction of different social groups ${ }^{29}$; only the law that takes the form of a general and abstract norm can well adapt to the liquid essence of cyberspace, an elusive reality as it is incorporeal, in which the nomos of hayeckian inspiration arises in katechontic $^{30}$ function against digital disorder.

Competition allows us to gather and mobilize knowledge dispersed over time and in social space, as it represents a process of discovery of knowledge itself and of emancipation from collective ignorance. In this way, the understanding of the social order within cyberspace can take place through the interpretation that Bruno Leoni offers of law and democratic rules: in a prescriptive order we are told what we can do while in a free society, where social cooperation exists, we are told what we cannot do, leaving ample freedom to any kind of licit interaction.

Law understood as a general and abstract norm marks the operational boundary between lawful and illicit actions, as it conveys individual behavior and prevents the invasion of the sphere of autonomy of others and the alteration of the competitive allocation of resources, which constitutes the source of freedom and unanimous equality and allows the exploration of the unknown space and the correction of errors that facilitates social cooperation ${ }^{31}$.

In the world of the Internet, the failure of traditional political representation in creating feedback that positively changes the social environment receives an opportunity for redemption through the birth of virtual communities that become cyberspace protagonists, allowing ever-broader sections of society to become active parties in that participatory process called digital democracy; in this way the transformation of the 'people' takes place, recognized as a juridically codified collective entity which is expressed through the rule of the majority, in what Leoni called 'public opinion', a juridically non-codified meta-juridical entity that is able to influence the decisions of the government bodies ${ }^{32}$

\section{Public Opinion in the Cyberspace: the notion of power}

The spread of digital communication, both through home computers and mobile devices, has favored the development of interactive communication networks capable of connecting the global aspect with the local aspect of social relations. The telematic metamorphosis of mass communication, which occurred in industrial society through the distribution of 'one to many' messages, is innervated in the global system of networks that allows, through multimodal interconnections, the exchange of interactive messages 'many to many ${ }^{133}$. The increasingly extensive use of digital technology has thus enabled the emergence of "virtual communities" 34 in which the sharing of ideas and opinions becomes the constitutive principle of the community itself.

Social networks are living arenas that connect every dimension of human life: their users transcend the dimensions of time and space, but produce suggestions, propagate opinions, give life to politics. Today the world is constantly connected by a global network that makes every dimension of human experience public; those who sail in cyberspace coevolve thanks to constant and diversified interactions.

The high degree of complexity and social differentiation that occurred in post-industrial communities, involved in the mass media revolution and the development of telematics and robotics has challenged the power relations of the physical world through facilitated access to a multitude of information that put the demos in a position to contextualize and evaluate the quality of political action, at the same time increasing the sense of bewilderment of the individual within an environment that does not recognize and in which he does not recognize himsel ${ }^{35}$.

It's in the concept of public opinion that we can find the contextualisation of Bruno Leoni's democratic praxis in the virtual reality of the Web: it presents itself in the dual capacity of a political ideal, understood as the aim of the democratic state and as a social reality that determines the will of a community not organized by codified law ${ }^{36}$. Interpreting Habermas, public opinion represents that 'world of life' that is characterized by communicative action, 
shared values, spontaneity, traditions: it is the place where "speaker and listener meet, in which they can mutually advance the claim that their expressions harmonize with the world (the objective, social and subjective) and in which they can criticize and confirm these claims of validity, externalize their dissent and reach agreement" ${ }^{37}$.

It turns out to be the index of the efficiency of a democracy, as it does not contribute to the constitution of relations that become entangled in the relationship majority-minority, but favors instead an exchange of multilevel relations thanks to its fluid essence ${ }^{38}$. What Norberto Bobbio calls a "procedural" definition of democracy ${ }^{39}$, meaning the method for taking collective decisions, in Leoni is crystallized in the theory of the "exchange of powers" 40 .

In cybernetic terms power is a circulating means within the political system, meaning by this term the activity of addressing and controlling the 'coordinated expectations ${ }^{141}$ of individuals, such that they coordinate the mutual efforts for the achievement of the aims of the comunity. Power is therefore similar to a system for guiding a machine, a mechanism for checking and controlling the damage of the system, which appears to be diluted in all social relations, like a flow that can increase or decrease and is bound to achieve a specific purpose.

The cooperation based on the coordination of expectations determines the fiduciary dimension that becomes fundamental: trust is gained by linking the coordination of human actions (energy) to the coordinated expectation of the same actions (information). In procedural terms it can be concluded that the stable coordination between expectations and actual behaviors, between information and energy, produces social cohesion, which is the measure of the degree of order that a state is able to guarantee in a democratic regime; cohesion translates into the result of an informative process that has been accepted on an individual level becoming an expected condition. To exercise power, therefore in order to obtain obedience, the individual must act through collectively accepted and understood communication channels.

For Leoni too, the social order stems from an understanding of the meaning of human actions and the expected results that come from their interaction ${ }^{42}$, based on the Latin motto id quod plerumque accidit, which symbolizes the legitimacy of expectations with a high degree of probability to be able to achieve ${ }^{43}$.

In this theoretical framework, public opinion is at the center of this spontaneous system of cooperative exchange that Leoni identifies with a peaceful state, which is characterized by descending from two lines of research well known to the doctrine, starting from the Leonian definition of power ${ }^{44}$ : the first, which investigates the procedure of group decisions and the ability of some men to know how to impose the his own will on that of other men and that constitutes a state of exception, comparing to the state of war; the second, which takes into consideration the human condition in society characterized by peaceful coexistence because it is based on the compatibility between actions and aims of individuals. In addition, individuals establish voluntary cooperation based on exchanges of behaviour, that is, on complementary actions that positively facilitate each other's goals. Compatible and complementary actions need to be understood within forecasting schemes of mutual conduct (rules) that allow individual interactions to take place peacefully. Finally, the compatible and complementary actions that take place within certain rules are the object of the power exercised by the actors who are its protagonists: such is the widespread power assisting the members of the community in their claims and forecasts of the behaviour of others ${ }^{45}$.

The equilibrium is maintained when the state is established, not intended as a collective entity identifiable in a set of rules codified in the Kelsenian sense, but as a "status", as a situation par excellence in which there is stability and normality of human relationships, in which ,individuals exchange the power to respect each other and to respect assets that they consider fundamental“" ${ }^{46}$. On the basis of this premise, the fluidity of the relationships between those who are obliged to obey and those who impose choices, is founded in such a way that the parts can be reversed by conditioning, determining social equilibrium.

The Leonian status is characterized by a constellation of horizontal powers that are likely to be exchanged because they are connected to a utility function, through which each individual tries to constantly improve his starting situation; it is a policentric order where the exchange of powers is, ultimately, the "status" structure ${ }^{47}$. The political community grows and stabilizes through this exchange, which will also be the premise for legal exchanges.

In this way, Leoni anticipates what in the cyberspace will complete the erosion of the state as an anfibiologico concept, ,a half emerging from the empirical-sociological perspective, half steeped in juridical doctrine, for which the state results from inter-individual psychological relationships, but expresses itself unitarily as a subject of law endowed with its own will“"48; the digital meta-juridical state translates into concrete terms the empirical theory that Leoni never completed, but which anticipated post-modern criticism of the meta-narratives of modern society ${ }^{49}$. 
In the immensity of the virtual world the borders of the state dissolve, revealing the inconsistency of the very concept of state and bringing out the true protagonist of social life: the individual. The methodological individualism of Weberian inspiration that guides Leoni's thought finds a further form of realization in digital society, becoming part of a social order that is not coercively established and where minorities have concrete possibilities to express their ideas without undergoing any form of political legitimacy. For Leoni, individual rights, understood as powers that are exchanged, therefore political powers, are pre-state, come before the state and legal order; they are, indeed, the premise of juridical activity itself and the intimate essence of the state.

Digital modernity represents the overcoming of exasperated statism in the coordination of social relations and in the production of law: in physical reality, political power controls the production of law, which is substantiated by the promulgation of laws that are a manifestation of the will of the state itself, realizing the definitive separation between law and society ${ }^{50}$.

In the Leonian public opinion this lost relationship is linked, thanks to the pervasiveness of individual powers is embodied in the active participation of broader segments of the population in political life, guaranteed by the inclusion offered by social media, which are characterized by being interactive media, thanks to which users consume, produce, evaluate and exchange information ${ }^{51}$.

\section{Conclusions}

Taking into due account the critical aspects that the issue of the presumed democratizing potential of the data transmission network entails ${ }^{52}$, the relevance of Bruno Leoni's thought could extend and contribute to structuring the complexity of cyberspace and the dimension of democratic principles interpreted through modern telematic technologies that characterize the further evolution of the Information Society. The model of direct democracy imagined by Leoni finds its actualization in the dynamics that take place within the virtual communities, net of the increasingly intrusive narcissism and "hyper democracy" feared by Ortega y Gasset ${ }^{53}$ that complicates and renders the goodness of digital arenas invisible to critical eyes.

The purpose of this paper is to operate a contextualization of Leonian thought on law and democratic representation in the current social dimension, whose expression is increasingly realized through interactive media; the law, democracy and the centrality of the individual in the world find their reconfiguration in this century where the tendency to consider the human being as an ontologically outmoded entity triumphs more and more ${ }^{54}$.

Liberal ideas originating from the Austrian school of economics, particularly the spontaneous order of von Hayek and the methodological apriorism of von Mises seem to echo in the work of John Perry Barlow on cyberspace ${ }^{55}$, while Carl Schmitt's nomos finds its nemesis in the absence of physicality of Internet facilities: here, the transformation of law and politics takes place on the basis of the constant presence of the citizen on the web, enhanced by the global reach of information circulating in social media.

The comparison between the principles of cybernetics and Leoni's theses on juridical and political representation serves to highlight the a priori paradigm that underlies both the mechanism of feedback, and the theory of claims and the exchange of powers: the claims and powers examined by Leoni appear to be based on the same $a$ priori and probabilistic framework on which the coordinated expectations elaborated by Karl Deutsch are based. "Claims" and "feedback" seem to well express the Misesian praxeological concept of human action ${ }^{56}$ aimed at improving a starting situation, since praxeology does not study the teleological aspect of action, but the means used to achieve this result. Rational but still fallible action, since the subjective perception of reality is not always in line with the objective one: if there is a knowledge capable of expressing itself through structured communication flows, there is a latent knowledge that is impossible to codify that can be acquired through empirical practice.

Like the market, the state is generated by a rational encounter of individual knowledge which is able to perceive and apply the rules of civil coexistence, but which cannot explain how to remove that natural imbalance present in individual life. Even if in the cybernetic school of politics the state continues to be considered as an autonomous entity, what is most relevant is to note how this is described more as a sort of computer that processes the information it receives from the community. 
Cybernetics come to understand the importance of individual interaction mechanisms to understand the dynamics of diffusion of power, which is nothing but a control system that emanates from political relations that exist before the state: even the examination of the state of war, as in Leoni, highlights how coercion is an exceptional situation, since it localizes power in a few communication centers that prevent the positive feedback process; in this way the communication system is closed to learning, preventing the automatic correction of the mistakes made.

Knowledge, communication, interaction: these are the watchwords in the web society: a society in constant flux because it grows through the unlimited spread of ideas and the perception of reality by individuals who realize their moral and personal independence in virtual communities, do not suffer the 'activity of the institutions, but strengthen it through the exchange of compatible and complementary actions, through positive feedback that allow the system to grow by learning from its mistakes. This creates the cognitive balance that allows the human being to no longer be afraid to explore the unknown, especially the digital one.

Bruno Leoni's political theory still demonstrates his immense adaptability to the passage of time, regardless of the extreme complexity that is characterizing today's society.

\section{Notes}

1. Leoni, B. 1961, Freedom and the Law, expanded 3rd edition, foreword by A. Kemp, Carmel, IN:Liberty Fund. It. tr., (1995), La libertà e la Legge, Macerata: Liberlibri.

2. Rosenbleuth, A., Wiener, N. and Bigelow, J. 1943, "Behaviour, Purpose and Teleology", Phylosophy of Science, 18-24.

3. Deutsch, K. W. 1963, The Nerves of Government: Models of Political Communication and control, New York: The Free Press of Glencoe. It. tr. 1972, I Nervi del Potere,Milano: Etas Kompass. Both Deutsch and Wiener, examining and defining the concept of feedback, took as a reference the cannon pointing system on military ships.

4. Machlup, F. 1962, The Production and Distribution of Knowledge in the United States, Princeton, NJ: Princeton University Press.

5. Almost 29 percent of U. S. gross national product.

6. It's very interesnting to note that the author himself proposed to cease using the terms «information» and «knowledge» as dichotomous, as if the first was referred to a series of facts without any connection, while the second to interrelated events. In this way the two terms become synonyms and usable in the cybernetic interpretation of society. Ivi, p. 8.

7. Smith, A. 2007 (1776), An Inquiry into the nature and causes of the Wealth of Nations, MetaLibri Digital; it. tr. 2017, La Ricchezza delle Nazioni, Milano: Utet. For Smith, knowledge and skills were variables of the human capital stock, which represented the embodied ability to perform labour, thus producing economic value.

8. Bell, D. 1973, The Coming of Post-industrial society: A venture in Social Forecasting, New York: Basic Books.

9. Ivi, p.19.

10. The mechanism of feedback.

11. Think about the 1976 Sidney Lumet movie "Network" or the work of Giovanni Sartori (1997) concerning the influence of television on the political choices of the average person exposed in the book Homo Videns. Televisione e Post-pensiero, Roma-Bari: Laterza. The observations that Walter Lippmann provides already in 1922 on the interpretation of information by individuals are very important: every human being is endowed with a pseudo internal environment that processes the information collected by mass communication channels, then influencing the way of communicate them outside. The end result will be a sort of cognitive distortion resulting from the ability of individuals to manipulate such information, distinguishing between the reality of the facts and the narrative that is given. See Lippmann, W. 1997, Public Opinion, New York: Free Press Paperbacks. It. tr. 2018, L'Opinione Pubblica, Roma: Donzelli.

12. Gibson, W. 1982, "Burning Chrome”, Omni Magazine, now publshed by Gollancz. It. tr. (2014), La Notte che Bruciammo Chrome, Milano: Mondadori.

13. The progenitor of the internet is considered the Arpanet project, that is, a program by the U. S. Defence Advanced Research Projects Agency scientists to create a continental network for connecting all computers. 
14. Schmitt, C. 1997 (1950), Der Nomos der Erde im Völkerrecht des Jus Publicum Europaeum, Berlin: Duncker \& Humblot. It. tr. 1991, Il Nomos della terra nel diritto internazionale dello Jus Publicum Europaeum, Milano: Adelphi.

15. On the concept of nomos against legislation see von Hayek, F. 1982, Law, Legislation and Liberty, London: Routledge, It. tr. 2010, Legge, Legislazione e Libertà. Critica dell'economia pianificata, Milano: Il Saggiatore. Leoni, B. 1991, Freedom and The Law, cit.

16. Above all, Sartori, G. 1987, The Theory of Democracy Revisited, London: Chatam House. Morlino, L. 2011, Changes for democracy: actors, structures, processes, Oxford: Oxford University Press. It. tr. 2019, Democrazia e mutamenti. Attori, strutture e processi, Roma, Luiss University Press. Dahl, R. A. 1977, Poliarchy:Participation \& Opposition, Yale: Yale University Press. It. tr. (1997), Poliarchia. Partecipazione e Opposizione nei sistemi politici, Milano: Franco Angeli.

17. Sartori, G. (2012), Democrazia, cosa è?, Milano: Bur Saggi, p. 367.

18. Deutsch, K. W., The Nerves of Government, cit., p. 25.

19. Ivi, pp. 35-36.

20. The black box imagined by David Easton is no longer able to emit coherent outputs, since the gatekeepers, the political parties, are no longer able to select the citizens' requests and to aggregate them in general themes considered sufficient to satisfy the needs of the society. See Easton, D. 1953, The Political System: An Inquiry into the State of Political Science, New York: Alfred A. Knopf. It. tr. 1963, Il Sistema Politico, Roma-Ivrea: Edizioni di Comunità.

21. Leoni, B. 1961, Freedom and the Law, op. cit.; Robilant, E. (1982,), "Diritto e Società Tecnologica nel pensiero di Leoni”, Il Politico, 47 (1):147-154.

22. In this way, Leoni approaches Anthony Downs's theory of rational ignorance and slightly anticipates the theory of decision-making costs of Buchanan and Tullock. See Downs, A. 1957, An Economic Theory of Democracy, New York: Harper Collins. It. tr.1988, Teoria economica della Democrazia, Bologna: Il Mulino. Buchanan, J., Tullock, G. 1962, The Calculus of Consent: Logical Foundations of Constitutional Democracy, Ann Arbor: University of Michigan Press. It. tr. 1998, Il Calcolo del Consenso. Fondamenti logici della Democrazia Costituzionale, Bolgna: Il Mulino.

23. According to Leoni, "the procedure is solely the modality or set of methods by which privileged character is attributed to a certain decision which, taken by certain individuals within the group, becomes, for this privileged character, the decision of the group “. Leoni, B. 2004, Lezioni di Dottrina dello Stato, Soveria Mannelli: Rubbettino.

24. In a paper from 1954, "Democracy, socialism and rule of law", Leoni approaches the conclusions that Lawrence Lowell describes in his 1913 volume "Public Opinion and Popular Government" when he claims that a community can be defined as cohesive if it also takes into account of the expression of minorities.

25. Popper, K. 1945, The Open Society and Its Enemies, 2 Voll., London: Routledge, p. 576; it. tr. (1973-1974), La società aperta e i suoi nemici, Roma: Armando editore.

26. Leoni, B. 2003, Lezioni di Filosofia del Diritto, Soveria Mannelli: Rubbettino. "The claim is the request of another's behavior considered by those who request it as probable and corresponding to their own interest, as well as determinable with some kind of intervention, if this behavior does not occur spontaneously, on the basis of a power of which the suitor considers himself gifted". In cybernetic terms, the claim can be seen as a feedback system, as it provides not only for the a priori forecast that the claim exercised is executed, but also involves the control phase of its realization, by means of the intervention aimed at modifying the behavior others.

27. Virilio, P. (1977), Vitesse et Politique: Essai de Dromologie, Paris: Editions Galilée. En. tr., 2006, Speed and Politics, LA: Semiotext. Also Petrocco, G. 2017, Diritto e Sistema Dromocatico.Hayek e Kelsen a confronto, Roma: Sapienza University Press.

28. Just think about the role of ICANN, an international public organization in ensuring the security of the interoperability of computers that communicate on the Internet.

29. Bifulco, R. 2018, “Intelligenza Artificiale internet e ordine spontaneo”, Aa. Vv., (2018), Intelligenza artificiale, protezione dei dati personali e regolazione, Milano: Giappichelli.

30. Schmitt, C. 1954, Land und Meer; eine weltgeschichtliche Betrachtung, Stuttgart: Klett-Costa. It. tr. 2002, Terra e Mare. Una riflessione sulla storia del Mondo, Milano: Adelphi.

31. Strong is the influence on Leoni of the German jurist von Savigny who, in parallel with the Scottish moralists Smith and Hume, dismantles the myth of the great legislator who knows everything and substitutes it with a customary evolutionary law, spontaneous creation of individual peoples. 
32. Leoni, B. 1946, "Il concetto di Pubblica Opinione", Rivista di Filosofia, (3-4): 124-152. The technological society concretizes the crisis of the traditional figure of the political man as an intermediary between the citizen and the institutions: homo telematicus does not need intermediation, but becomes a representative of itself in the digital agora. The recent survey “European Tech Insights 2019", presented by IE University and developed by the Center for the Governance of Change, highlighted that a quarter of the population of the 7 European countries considered favorably expressed the replacement of politicians with artificial intelligence to make decisions regarding public policies.

33. Castells, M. 2012, Networks of Outrage and Hope. Social Movements in the Internet Age, Cambridge: Polity. It. tr., 2012, Reti di Indignazione e Speranza. Movimenti Sociali nell'Era di Internet, Milano: Università Bocconi Editrice.

34. "Virtual communities are social aggregations that emerge from the network when a certain number of people carry out public discussions long enough, with a certain level of human emotions, so as to form networks of personal social relations in cyberspace". In the words of Howard Rheingold it is possible to find the theoretical basis from which the social networks and also the "smart mobs", groups of people using mobile devices and telematic networks to promulgate coordinated collective actions, have branched out; in this way, the participants in the "smart mobs" become receptors and transmitters of the messages that spread in cyberspace and are then executed in the real world. See Rheingold, H. 1993, The Virtual Community: Homesteading on the Electronic Frontier, Boston: Addison-Wesley. It. tr. 1994, Comunità Virtuali. Parlare, Incontrarsi, Vivere nel Ciberspazio, Sperling \& Kupfer. Id. 2003, Smart Mobs: The Next Social Revolution, New York: Basic Books. It. tr. 2003, Smart Mobs. Tecnologie senza fili, la rivoluzione sociale prossima ventura, Milano: Cortina Raffaello.

35. Zolo, D. 1996, Il principato democratico, Milano: Feltrinelli. Luhmann, N. 1982, The Differentiation of Society, New York: Columbia University Press.

36. Leoni, B., Il concetto di “Pubblica Opinione”, cit.

37. Habermas, J. 1981, Theorie des kommunikativen Handelns, vol. 2, Berlin: Suhrkamp Verlag. It. tr. 2017, Teoria dell'agire comunicativo, vol. 2, Bologna: Il Mulino. Habermasian democracy finds legitimacy in the discursive and communicative capacity of citizens, that is, in their willingness to relate through dialectical confrontation on the most important issues of social life in order to reach a more shared consensus. From this dynamic, the German sociologist understands how social organization is related to a discursive rationality that is identified with the 'world of life', a transcendental place where communication and sharing allow those subjects involved in the dialogic process that, free to express their disagreement, can harmonize their expressions and reach an agreement; to this place an instrumentalized rationality is opposed by the political (strategic) power, that finds its fundamental elements in the money and the power, and that is correlated to a technical and instrumental action that ends up creating a rigid systemic organization in which it is the will of a few that imposes itself on the totality of individuals. Through public opinion as seen by this point of view, it would also be possible to prevent the 'spiral of silence' which, according to Elisabeth Neumann, would arise from the imposition of the ideas of an overwhelming majority, isolating any expressions of disagreement.

38. The 'waterfall model' by Karl Deutsch is the best example that serves to give a more precise image of this statement. five are the communication levels: the first one is the reservoir in which information and decisions are made by the socio-economic elites, who pour their flow directly into the second reservoir, the one in which the political and government bodies carry out their activities; from this reservoir, drops a further jet that flows into the mass media tank, from which a further flow that reaches the level of local leaders, representing the minimum percentage of people who are really interested in politics and who are attentive to the messages of the average; thanks to these prerogatives these characters are able to influence the mass audience, which represent the last reservoir into which the information flows that have gone through various adaptations and manipulations converge. Important thing to note is that this process involves a continuous shuffling of information, as each level is characterized by multiple communication channels and the more the individual levels are distant from each other, the less the less the mutual influence that the various tanks will have. they can exercise between them; moreover, the presence of feedback puts the groups of the lower levels in the condition of being able to oppose and reject the information received from above and to proceed to reinterpret and redirect their opinions to higher levels (bubbling up ). See Deutsch, K. 1968, The analysis of International Relations, Englewood Cliffs, N.J: Prentice Hall.

39. Bobbio, N. 2005, Il Futuro della Democrazia, Torino: Einaudi.

40. Leoni, B. 1997, Le pretese e i poteri. Le radici individuali del diritto e della politica, Milano: Società Aperta. 
41. Deutsch, K. W. 1963, The Nerves of Government, cit.

42. Strong is the influence of Carl Menger's social theory, of the "methodological apriorism" of von Mises and the theory of the sensory order of Von Hayek, very close to the definition of feedback; according to this theory, human reason is very limited and people develop 'ideas' through intuition and in a passive way. The human mind is incapable of understanding the fundamental rules that govern its own operations, but the senses are able on their own to discern recurrent patterns or order in events, without resorting to mental operations. The ability of the senses to recognize spontaneous patterns is superior to the mind's ability to define such patterns. Sometimes the senses are able to 'theorize' and react to the unconscious inferences that occur in perceptions and the conscious thinking is governed by a superconscious (in itself not conscious) mechanism that operates on the contents of consciousness. This superconscious or 'metaconscious' mechanism is the sensory order of neural connections. The sensory order of a person originally is actually based on a 'pre-sensory experience', which is 'knowledge' embedded in the structure of the mind. This experience exists before an individual acquires concrete experience in the world and is the result of the inherited biological and cultural experience of the human species. See Von Hayek, F. 1952, The sensory Order, Chicago: University of Chicago Press.

43. It is more probable that a creditor can demand the return of his money that a pickpocket can claim not to be robbed.

44. "Power is the possibility to make correspond to our desire those determined events of the external world that are the behaviors of the people that obey us", Leoni, B. 2004, Lezioni di Dottrina dello Stato, cit.

45. These interrelated sequences are defined by Leoni as: "the pure social aspect" of society; the "economic aspect" of society; the "legal aspect" of society; "the political aspect" of society. From them a form of power is generated that guarantees social balance. See Stoppino, M. 2000, Potere ed Élites Politiche. Saggi sulle Teorie, Milano: Giuffrè, p. 281.

46. Leoni, B. 2009, "Diritto e Politica”, in Id., 2009, Scritti di Scienza Politica e Teoria del Diritto, Soveria Mannelli, Rubbettino.

47. On the pervasiveness of powers in society, Leoni anticipates what will also be the intuition of Michel Foucault. See Foucault, M. 1977, Microfisica del Potere. Interventi Politici, Tornino: Eianudi. But he comes close to what Georg Simmel claimed in the early twentieth century, seeing exchange as the very essence of power and society. See Infantino, L. 2017, “Potere e Libertà in Bruno Leoni”, Lo Stato. Rivista Semestrale di Scienza Costituzionale e Teoria del Diritto, Modena, Mucchi Editore, (9): 33-47.

48. Raffaele de Mucci, in the Preface to the Lezioni di Dottrina dello Stato, cit., defines "anfibiologic" the State as theorized by Jellinek and object of Leoni's criticisms.

49. One above all, the Hegelian idea of the end of history in the triumph of rationality related to the extension of the codification of law, an idea defended by the Franco-Russian philosopher Alexandre Kojève.

50. Grossi, P. 2015, Ritorno al diritto, Roma-Bari: Laterza.

51. The reference is to the use that political communication makes of social networks like Twitter, which stimulate the immediate response of followers to the inputs offered by politicians' statements. Through public opinion as seen by Leoni, it would also be possible to prevent the spiral of silence which, according to Elisabeth Neumann, would arise from the imposition of the ideas of an overwhelming majority, isolating any expressions of disagreement.

52. See Morozov, E. 2012, The Net delusion: How to liberate the World, London: Penguin. It tr. 2012, L'ingenuità della rete. Il lato oscuro della libertà di Internet, Torino: Codice edizioni.

53. Ortega y Gasset, J. 1943, La Rebeliòn de las Masas, Madrid: Espasa-Calpe. It. tr., 2001, La Ribellione delle Masse, Milano: SE Editore.

54. The reference is to studies on transhumanism and posthumanism, anticipated by Norbert Wiener's analyzes of the similarities in the functioning of biological organisms and calculating machines.

55. A Cyberspace Declaration of Independence, 1996, 9 February.

56. Von Mises, L. 1949, Human Action. A Treatise on Economics, Carmel: Liberty Fund. It. tr. 2016, L’Azione Umana. Trattato di Economia, Soveria Mannelli: Rubbettino. 